\title{
How Much Does Islamic Corporate Social Responsibility Affect Zakat Performance? Data Processing Using Eviews
}

\author{
Friztina Anisa ${ }^{1}$, Veni Soraya Dewi ${ }^{*}$, Nur Hidayah $^{1}$ \\ ${ }^{1}$ Department of Management, Universitas Muhammadiyah Magelang, Magelang, Indonesia. \\ ${ }^{2}$ Department of Accounting, Universitas Muhammadiyah Magelang, Magelang, Indonesia. \\ *Corresponding author. Email: venisorayadewi@ummgl.ac.id
}

\begin{abstract}
This study aims to determine whether ICSR management influences the zakat performance ratio (ZPR), at Sharia Commercial Banks in Indonesia. ZPR is one indicator of financial performance used in Islamic banking, the Islamicity Performance Index, which is a comparison between the amount of zakat and net assets owned by Sharia Commercial Banks. Based on Al Quran and Hadiths ICSR management must be able to reach all aspects of the company and benefit for the entire community, including the recipient of zakat. Based on Sharia Enterprise Theory, the management of ICSR will affect ZPR which is the highest responsibility of an Islamic-based company is to Allah SWT and paying zakat is responsibilities that must be carried out by the company. However, in reality, some of Sharia Commercial Banks may be do not carry out these obligations so it will affect the performance of the BUS. The method in this study is linear regression use Eviews statistical analysis. The data obtained from annual reports of Indonesia Islamic banks at 2013-2017. The results of this study stated that the disclosure of CSR funds negatively affected the Zakat Performance Ratio. Keywords: Islamic CSR, Zakat Performance, Eviews
\end{abstract}

\section{INTRODUCTION}

Maximizing the value of the company is the main goal of all activities carried out by the company. These activities will definitely have an impact on both internal and external parties in terms of financial and non-financial. One of the activities that must be carried out and budgeted is Corporate Social Responsibility (CSR), as a form of corporate responsibility to the surrounding environment in accordance with Law Number 40 of 2007 article 74 which is further stipulated in Government Regulation No. 47 of 2012.

Companies that carry out CSR will get a good image according to signaling theory. In signaling theory [1], it is explained that the company will convey good information to outsiders quickly so that those who know the information can respond immediately. Outside parties who receive the information do not simply believe but will look for some evidence to confirm the truth. In this case, CSR carried out by the company can be seen in the company's annual report, both its activities and the amount. Thus, it is hope investors and consumers will see this as a good signal so that the company's performance will also increase. Both capital and company profitability will increase as a company's CSR disclosure is met. CSR has a positive influence on company performance [2], CSR influences company performance by being moderated by company size [3], CSR has a positive and significant effect on firm performance in Indian companies [4]. Different results state that CSR Disclosures have a negative effect on CFP (Corporate Financial Performance) [5], CSR has no effect on EPS [6].

Islamic Corporate Social Responsibility (ICSR) is a concept of corporate social responsibility in the dimensions of Islamic economics, law, ethics, and philanthropy based on Al Qur'an and Hadiths [7]. This means that all CSR activities must be in accordance with the guidance of the Qur'an and Hadiths whose responsibilities are not only to the stakeholders but also to Allah SWT, this is accordance with Sharia Enterprise Theory.

One of the concepts of ICSR is zakat. Zakat aside as worship is also a tabaru aspect (corporate social aspect) which is a corporate obligation that must be carried out in order to create a balance in carrying out its business activities [8]. Zakat Performance Ratio (ZPR) is a proxy of the Islamicity Performance Index which is an indicator of Islamic banking financial performance. Through the Islamicity Performance Index approach, it can be seen the performance of Islamic banks in terms of economics and Islamic values contained in the Islamic bank [9]. ZPR is calculated based on a comparison between the amount of zakat and net assets owned by a Sharia Commercial Bank. ICSR management in accordance with the Qur'an and Hadiths must be able to reach all aspects of the company and benefit the entire community, including the recipient of zakat. Based on Sharia Enterprise Theory, corporate responsibility is not only to stakeholders and shareholders but more broadly to Allah SWT [10], the management of ICSR will affect ZPR and paying zakat is a manifestation of that responsibility. Zakat is an obligation of the company as the object of zakat [11]. However, in reality there may still be many Sharia Commercial Banks that do not carry out 
these obligations. This can be seen in several Sharia Commercial Bank financial reports in Indonesia that do not include zakat in it. The amount of zakat should appear on the profit/loss statement so that the net profit of Sharia Commercial Bank is profit after tax and zakat.

The performance of Islamic banks must be based on the payment of bank zakat to replace conventional performance indicators, namely earnings per share (EPS) [12]. The main pillar of the Islamic economy mentioned in the Qur'an is the fiscal mechanism of zakat [13]. The word zakat in the Qur'anic terminology is the same as the word Sadaqah [14]. Zakat is a compulsory levy on individuals who have the obligatory property of zakat which has nishab (muzakki) and is distributed to the recipients of zakat (mustahik), namely: the needy, poor, fisabilillah, ibnussabil, amil, gharimin, servant sahaya, and converts [13]. Some of the benefits of zakat for the economy include increasing the level of aggregate consumption, increasing the level of national saving, and increasing allocative efficiency [15]. The contribution of this study is to measure the performance of companies using ZPR as a substitute for EPS because the Sharia Commercial Bank must be in accordance with Islamic principles. This study aims to determine whether ICSR management influences the zakat performance ratio (ZPR), at Sharia Commercial Banks in Indonesia.

\section{METHOD}

This research is included in descriptive quantitative research that aims to determine the value of variables independently, either one or more variables without making comparisons, or connecting with other variables [16]. Statistical data and figures are used to explain the results of the study. The population of this study is Islamic banking in Indonesia, which is Sharia Commercial Banks. The sampling technique used was purposive sampling technique, that is Sharia Commercial Banks in Indonesia and has published financial reports in a row for 5 years, namely in 2013-2017 and did not change shape during the observation period. The time span of 5 years is used because it has fulfilled the generalization of results. Eviews are used as a regression analysis tool because the data used are panel data that is data that consists of several time periods and several Sharia Commercial Banks as research objects.

Because the data used is panel data, the regression analysis tool used is Eviews. Panel data is data that consists of several objects and several periods of research [17]. The variables in this study are ICSR as an independent variable and ZPR as the dependent variable. Table 1 presents the measurements of each variable used in the study.

Regression models:

Information:

$$
\mathrm{Y}=\alpha+\beta . \mathrm{X}+\mathrm{e}
$$

$$
\begin{array}{ll}
\alpha=\text { constanta } & \mathrm{Y}=\text { Zakat Performance Ratio } \\
\beta=\text { koefisien } & \mathrm{e}=\text { error } \\
\mathrm{X}=\mathrm{ICSR} &
\end{array}
$$

Table 1 Variable measurements

\begin{tabular}{|ccc|}
\hline Variable & Measurement & Scale \\
\hline ICSR & $\begin{array}{c}\text { The amount of CSR funds } \\
\text { issued by Sharia } \\
\text { Commercial Banks every } \\
\text { year }\end{array}$ & Nominal \\
\hline $\begin{array}{c}\text { Zakat } \\
\text { Performance } \\
\text { Ratio }\end{array}$ & $\begin{array}{c}\text { Zakat divided by net } \\
\text { assets }\end{array}$ & Ratio \\
\hline
\end{tabular}

\section{RESULTS AND DISCUSSION}

In panel data regression, there are three models that will be selected as the best model, which is common effects, fixed effects, and random effects. The best model that will be used is chosen through several tests, that is chow test, LM test, and hausman test [17].

\subsection{Test the Common Effect and Fixed Effect Models with Chow Tests}

Table 2 presents the results of the chow test. From the results of the Chow Test, the results obtained that the value of the probability of cross-section $\mathrm{F}$ is $0.5220>0.05$, then Ho is accepted and the study uses the Common Effect model, so that the LM test and the test result need not be done.

Table 2 Result chow test ZPR

\begin{tabular}{|cccc|}
\hline Effects Test & Statistic & d.f. & Prob. \\
\hline Cross-section F & 0.831021 & $(4,19)$ & 0.5220 \\
\hline $\begin{array}{c}\text { Cross-section Chi- } \\
\text { square }\end{array}$ & 4.030677 & 4 & 0.4019 \\
\hline
\end{tabular}

\subsection{Interpret the Common Effect Model}

Table 3 presents Linear Regression Test Results ZPR with Common Effect models.

Table 3 Linear regression test results ZPR with common effect models $\left({ }^{*} \alpha=10 \%\right)$

\begin{tabular}{|ccccc|}
\hline Variable & Coefficient & $\begin{array}{c}\text { Std. } \\
\text { Error }\end{array}$ & t-Statistic & Prob. \\
\hline C & 0.000353 & $4.97 \mathrm{E}-05$ & 7.118122 & 0.0000 \\
\hline CSR? & $-2.25 \mathrm{E}-15$ & $1.24 \mathrm{E}-15$ & -1.813160 & $0.0829^{*}$ \\
\hline R-squared & 0.125061 & & F-statistic & 3.287548 \\
\hline $\begin{array}{c}\text { Adjusted } \\
\text { R-squared }\end{array}$ & 0.087020 & & $\begin{array}{c}\text { Prob (F- } \\
\text { statistic) }\end{array}$ & 0.082880 \\
\hline
\end{tabular}

Based on Table 3, the effect of CSR funds on Zakat Performance Ratio can be written in the regression formula as follows:

$$
\mathrm{ZPR}=0,000353-2,25 \mathrm{E}^{-15} \mathrm{ICSR}+\mathrm{e}
$$

Constant 0,000353 means that if the ICSR variable does not exist or the value is 0 then ZPR has a positive value of 0,000353 . Regression coefficient of $-2.25 \mathrm{E}-15$ means that if 


\section{ACKNOWLEDGMENT} by $2.25 \mathrm{E}-15$. T test results indicate that $t$ arithmetic of 1.813160 with a significance value of $0.0829>0.05^{*}$, meaning that $\mathrm{H} 1$ is rejected or ICSR has no effect on ZPR. This result is supported by research [6] which states that CSR has no effect on EPS, where EPS as a conventional indicator is replaced by ZPR [12]. *At the $10 \%$ significance level, this result can still be accepted with a negative $t$ value $(-1.813160)$ which means that ICSR has a negative effect on ZPR.

$F$ value of 3.287548 and has a probability value of $F$ that is $0.082880>0.05$, it can be concluded that ICSR has no simultaneous effect on ZPR. The coefficient of determination is $12,5061 \%$ which means that the ICSR variable influences ZPR by $12.5061 \%$ and the remaining $87.4939 \%$ is influenced by other variables outside the study. From the t-test results obtained that the ICSR negatively affects the Zakat Performance Ratio. That is, the greater the ICSR funds issued by Sharia Commercial Banks, the less Zakat is issued. In accordance with Law Number 21 of 2008 article 4 paragraph 2 concerning sharia banking it is explained that Sharia Commercial Banks and Sharia Business Unit can carry out social functions in the form of baitul maal, that is receiving funds from infaq, waqf, alms, grants, or other social funds and channeling them to zakat distribution institutions as a form of trust from the community.

In accordance with the Sharia Enterprise Theory, corporate responsibility is not only to stakeholders and shareholders but more broadly to God [10] and allocating zakat is one form of fulfilling its obligations. But as a company that also makes a profit, zakat payments are based on the amount of profit obtaine. ICSR as one of the budgeted activities will automatically reduce Sharia Commercial Banks profit although not all CSR activities are charged to operational costs, so that if ICSR funds increase, the amount of zakat issued will be less.

\section{CONCLUSION}

The results showed that ICSR had a negative effect on ZPR, meaning that the greater the ICSR funds spent the smaller the amount of zakat distributed. Although the operations of a Sharia Commercial Bank based on the tabaru contract and its activities are not profit oriented, the Sharia Commercial Bank still calculates the benefits for its survival. This is what causes the calculation when issuing zakat based on the ICSR that has been issued. That way, Islamic commercial banks can still carry out their obligations, namely CSR and zakat at the same time by not ignoring the profits.

The limitation of this study is that not all Sharia commercial banks in Indonesia can be used as samples because some Sharia commercial banks do not provide the information needed in the study. Suggestions for further research is to add years of research so that the samples used become more and more research can be generalized.
The source of funding for this research came from LP3M University of Muhammadiyah Magelang through PRVI funding as a form of institutional support for lecturers to consistently conduct research.

\section{AUTHOR CONTRIBUTIONS}

Conceptualization (F.A); Material research preparation (F.A, V.S.D, N.H); Methodology (F.A, V.S.D); Data collecting (F.A, V.S.D, N.H); Data analysis and visualization (F.A, V.S.D, N.H); Writing - original draft (F.A); Presentation (F.A).

\section{REFERENCES}

[1] S. A. Ross, The determination of financial structure: The incentive signaling structure. Bell Journal of EconomicsNo Title, 1977.

[2] C. Mallin, H. Farag, and K. Ow-Yong, "Corporate Social Responsibility and Financial Performance in Islamic Banks," J. Econ. Bahavior Organ., vol. 103, Suppl, no. July, pp. S21-S38, 2014.

[3] J. J. Jekwam and S. Hermuningsih, "Peran Ukuran Perusahaan ( Size ) Dalam Memoderasi Corporate Social Responsibility Dan Likuiditas Terhadap Kinerja Keuangan Pada Perusahaan Pertambangan yang terdaftar di BEI," Upajiwa Dewantara, vol. 2, no. 1, pp. 76-92, 2017.

[4] N. Mitra, A. Akhtar, and A. Das Gupta, "Communicating Corporate Social Responsibility in the post mandate period: Evidence from India," Int. J. Corp. Soc. Responsib., vol. 3, no. 10, pp. 1-16, 2018.

[5] A. K. Irwanto, "Pengaruh Pengungkapan Corporate Social Responsibility terhadap Kinerja Keuangan dan Harga Saham pada Sektor Properti di Bursa Efek Indonesia Putri Fika Hidayansyah Responsibility (CSR) sebagai langkah nyata dalam memberikan sumbangan kepada," Manaj. dan Organ., vol. VI, no. 1, pp. 74-89, 2015 .

[6] A. Prasetyo and W. Meiranto, "Pengaruh Corporate Social Responsibility Terhadap Kinerja Keuangan Perusahaan Manufaktur Yang Terdaftar Di Bei," Diponegoro J. Account., vol. 6, pp. 1-12, 2017.

[7] M. A. Khurshid, A. Al-Aali, A. A. Soliman, and S. M. Amin, "Developing an Islamic Corporate Social Responsibility Model (ICSR),” Compet. Rev., vol. 24, no. 4, 2014 . 
[12] D. Duantika, “Analisis Perbandingan Kinerja Bank

[8] A. Kurniawan and Suliyanto, "Zakat Sebagai Aspek Tabaru Dan Pengungkapan Islamic Social Reporting Terhadap Kinerja Keuangan: Sebuah Agenda

Penelitian," J. Proceeding FEB UNSOED, vol. 18, no. 2 (2013), pp. 51-68, 2014.

[9] Shahul Hameed bin Mohamed Ibrahim, “"“Alternative Disclosure\&Performance Measures For Islamic Bank," J. Int. Univ. Kuala Lumpur dan Univ. Tenaga Nasional(UNITEN), no. Malaysia, p. 6, 2004.

[10] I. Triyuwono, "Sinergi Oposisi Biner: Formulasi Tujuan Dasar Laporan Keuangan Syariah," Iqtisad J. Islam. Econ., vol. 4, no. 1, 2003.

[11] D. Hafidhuddin, Zakat dalam Perekonomian Modern. Jakarta: Gema Insani, 2002.
Syariah berdasarkan RGEC dan Islamicity Performance Index," UIN Syarif Hidayatullah, p. 25, 2015.

[13] Ascarya, Akad \& Produk Bank Syariah. Jakarta: Raja Grafindo Persada, 2011.

[14] Mursyidi, Akuntansi Zakat Kontemporer. Bandung: PT. Remaja Rosdakarya, 2006.

[15] Y. Wibisono, Mengelola Zakat Indonesia. Jakarta: Prenada Media Group, 2015.

[16] Sugiyono, Metode Penelitian Kuantitatif, Kualitatif dan R\&D. Bandung: Alfabeta, 2015.

[17] Nuryanto and Z. B. Pambuko, EViews untuk Analisis Ekonometrika Dasar - Aplikasi dan Interprestasi, 1st ed. Magelang: UNIMMA PRESS, 2018. 